\title{
Some Recommendations of M\&A Activity in Vietnam Today
}

\author{
Phan Quan Viet \\ Department Business Management \& Trade International \\ Falcuty Business Management, Sai Gon University \\ 273 An Duong Vuong, 5 Ward \\ Ho Chi Minh City, Vietnam \\ Tel: 84-12-9749-9799_E-mail: dinhngochuong2003@yahoo.com
}

Received: September 22, 2014 Accepted: October 17, 2014 Published: March 30, 2014

doi:10.5296/ieb.v2i1.7893

URL: http://dx.doi.org/10.5296/ieb.v2i1.7893

\begin{abstract}
After 7 years of joining the World Trade Organization (WTO) in Vietnam, the businesses of Vietnam now have been integrating into the world economy increasingly deeper, not only having opportunities but also facing challenges. The benefits are very significant but the impact and adverse effect of the global economic crisis on the businesses of Vietnam is not small. During the integration process as above, M\&A activity is a tool to attract resource and expand business scale. In the economic recession, M\&A activity is an effective way to help the businesses of Vietnam get out of the recession and recover development. This article introduces the problems of the core of M\&A activity and also analyzes the results obtained in M\&A activity in Vietnam over the years and the impact of M\&A on the economy of Vietnam. On this basis, the author provides some basic solutions in M\&A activity in Vietnam.
\end{abstract}

Keywords: Aquisitions, Mergers (M\&A), WTO, Global economy, World economy 


\section{Overview of M\&A}

\subsection{What is $M \& A$ ?}

M\&A stands for the two English words of Mergers and Aquisitions. M\&A activity is to gain the control of a business through the ownership of a portion or the whole of that business. M\&A (mergers and acquisitions) seems to be a phrase pronounced together, with the same meaning, but in fact they have different characteristics and we need to understand between mergers and acquisitions:

Merger: a form of combination that the two companies which usually have the same size agree to pool their shares. A merged company transfers all its assets, its rights, its obligations and its legal benefits to the merging company, and to terminate the existence of the merged company to become a new company.

Acquisition: a form of combination that a company acquires or takes over another company and put itself in the position the new owner. However, this deal does not launch a new legal entity.

The purpose of M\&A is to gain the control of a business in a certain extent, not merely partial ownership of equity or shares in the business like small investors. So when an investor obtains the ownership of equity or shares of a business enough to participate and decide the important issues of the business, then this can be considered M\&A. Conversely, if the investor owns the equity or shares not enough to decide the important issues of the business, this is only considered normal investment activities.

\subsection{The Role of $M \& A$ Activity}

M\&A brings tremendous benefits to all parties involved. It not only helps large businesses reduce investment costs, help the weak businesses escape from bankruptcy risk but also help new businesses created after M\&A have full potentials and advantages to grow and gain competitive advantage in the marketplace.

For businesses that are making losses, with degradation or competitive advantage diminished, lack of adaptation to the new business environment. M\&A is a solution to help them avoid chronic losses. Even with businesses which are operating normally, M\&A is also a way to help them expand the scale, increase business opportunities, expand markets and gain market share from competitors. Because, M\&A not only helps businesses attract more capital like the stock market but also set up a strategic partnership with buyers, increase long-term and sustainable value for the business by capacity of management, good human resources, technological know-how combined with the existing distribution system of the buyers ...

For investors, M\&A is an effective way for them to step into the market quickly without having to spend time looking for a project or doing administrative procedures. Besides, M\&A also helps businesses save costs when establishing a new business, creating a new market and other costs incurred.

For newly formed companies, M\&A is a way for businesses to supplement defects and make 
resonance of power with each other, forming strength many times. Businesses can reduce their costs by cutting redundant and weak staff and raising labor productivity. Or through the transfer and complement of technology to each other, the labor productivity of the businesses will be increased. With large scale, new businesses will also have a favorable position when negotiating with partners, expanding marketing channels, and distribution system also increases faster.

\subsection{Benefits of $M \& A$}

Benefits are important motives which explain any acquisitions or merger. Effectiveness and value of a new business (after merger) is enhanced. The benefits that businesses expect after every M\&A include:

Reduction of staff: Often, when two or more firms merge, there are needs of staff reduction, especially indirect jobs such as office work, accounting finance or marketing. Reducing jobs also requires the requirement of increasing labor productivity. This is also a great opportunity for businesses to lay off inefficient working positions.

Achievement of efficiency based on scale: A large enterprise will have more advantages when conducting transactions or negotiations with partners. On the other hand, large scale also helps enterprises reduce unnecessary costs incurred.

Being equipped with new technology: In order to maintain a competitive advantage, companies themselves need constant investment in technology and techniques to overcome other competitors. Through mergers or acquisitions, companies may transfer techniques and technologies to each other, from which the companies can take advantage of technology transferred in order to create competitive advantage.

Strengthening market share and reputation in the industry: One of the goals of mergers \& acquisitions is expansion of new markets, growth of revenue and earnings. Mergers allow expansion of marketing channels and distribution systems. Besides, the position of the new company after merger will increase in the eyes of the investment community: bigger companies have more advantages and ability to raise capital more easily than small companies.

\subsection{The Difference between Mergers and Acquisitions}

Firstly, in the form of implementation: For the merger, all assets of the merged business will be transferred to the merged enterprise. On the other hand, the acquisition activity, not necessarily all of which sometimes only a part of the business assets being acquired have aggregate assets of acquired businesses. This depends on the size of the acquisition.

Second, the nature of transactions: Merger can understand the simple way is the two or more businesses (often the same size, nature) cooperation, consensus link into an enterprise to deliver largest overall benefits possible for the parties concerned. A merger nature of equity so called merger equilibrium.

But in fact, the majority of deals are usually very difficult to achieve consensus between the 
parties. Merging parties often will use multiple ways to "acquire" one or more parties to "disadvantaged" more. Once calculated, "friendly" does not exist, ie subject to repurchase does not want, even to implement the financial engineering to combat merged, then the activity purely of a commercial image acquisitions.

A merger or sale depends on goodwill, views and assessments of the leaders and owners of companies. But in fact, there are many cases where the acquired and the acquisition will negotiate and agree to transmit information to the outside that "this activity is equal merger and place a amicably between two or more parties, "though this is essentially purchasing activities.

Third, the legal consequences: For the merger transaction, after business registration, the merged business will totally cease to exist; while merging will now enjoy the rights and legal interests, as well as responsible for unpaid debts, labor contracts and other property obligations of the merged enterprise. Meanwhile, for repurchase transactions, after the contract takes effect, the acquired business will cease operations in part to the acquired parts; acquired businesses will be entitled to the rights and legitimate interests, liable for unpaid debts, labor contracts and other property obligations of the acquired businesses.

Thus, depending on the form of implementation, the nature of transactions, legal consequences, and some other factors that each of M\&A will be identified as operational merger or sale. It is also apparent from the difference of the two activities seemed very similar to this.

\section{Existing Situation of M\&A Activities in Vietnam}

In 2005, M\&A market of Vietnam was marked by the existence of the Enterprises Law of Vietnam, including the provisions on acquisitions, mergers and the policy of equitization of State enterprises was adopted. After that, other legal documents such as the Law on Foreign Investment 2005, the Securities Law 2006 came into existence also helped to boost M\&A activities taking place stronger. M\&A market of Vietnam flourished strongly from 2006 onwards; a great development from 22 business affairs with the total value of 61 million US dollars in 2005 has increased to 48 transactions corresponding to 490 million US dollars.

2007 is the most vibrant year of M\&A market of Vietnam, with the value increasing up to $475 \%$, reaching 1,719 million US dollars with a total of 108 business transactions. 2006, 2007 are two years with the highest growth rate thanks to Vietnam's joining the WTO on 07 November 2006. This event has made M\&A market in Vietnam strongly "attracts" foreign investors thanks to the implementation of international commitments on investment in Vietnam along with positive improvements in the legislation system and policies on foreign investment as well as investment environment.

During this time, the wave of acquisition of shares of joint-stock commercial banks of Vietnam takes place pretty excitingly. Foreign investors pouring money into Vietnam's commercial banks are none other than banking and financial groups in the world (HSBC, Dragon Capital, Deutsch Bank, Standard Chartered Bank, ANZ ...). These pioneer investors have soon become strategic shareholders in financial and banking sectors of Vietnam. 
As assessed by foreign investors, to operate in a new market and full of potentials like Vietnam, investors have many different forms of selection: Firstly, establishment of an enterprise with 100\% foreign capital; Secondly, development of branches; and thirdly, through M\&A activities. However, the most appropriate choice at this stage in Vietnam is M\&A activities.

Therefore, in recent years, we have witnessed a lot of business co-operation activities between domestic banks with foreign banks, such as the collaboration between HSBC and Techcombank, Habubank and Deutsche Bank, ANZ and Sacombank, Standard Chartered Bank and ACB. The business strategy of foreign banks is expansion of their scale of operation through the shortest path, that is performing M\&A with domestic banks. They look for and cooperate with partners that are joint-stock banks in Vietnam, because these banks are dynamic and have the ability to adapt quickly.

On their part, Vietnam's banks will have access to modern technologies of management from partners, taking advantage of the capabilities of finance and highly-qualified human resources, having the opportunity to learn experience in business. Besides, distribution is also an area of high attractiveness to investors. In 2006, four largest firms in the distribution industry of Vietnam including: Saigon Trading Group (Satra), Hanoi Trade Corporation (Hapro), Saigon Union of Trading Co-operatives (Saigon Coop) and Phu Thai Group signed a cooperation agreement on the establishment of Vietnam Distribution Network Development and Investment Joint Stock Company.

Statistical data shows in 2011 the total value of 400 M\&A business transactions reached nearly 4 billion US dollars, which increases compared with 3.5 billion US dollars in 2010. If compared with the figures of the year 2010: 350 business transactions, valued 3.5 billion UD dollars, the data on transaction value in 2011 establishes a new record. Looking at the graph of M\&A proportion with domestic factors, Vietnamese enterprises still increase both in value and business transactions. In 2012, the figure only reached 3.7 billion US dollars, an impressive growth compared with 3.1 billion US dollars in 2009. With a glance of 2013, the value of M\&A in Vietnam only reached 2.8 billion US dollars, tendings to decrease for 3 years from 2011-2013. If it was developing like that, it could be seen that the period from 2006 to 2011 was a period of strong growth of M\&A in Vietnam. This stage is the stage of formation of M\&A market in Vietnam from single business transactions into a market with the scale of nearly 4 billion US dollars. 


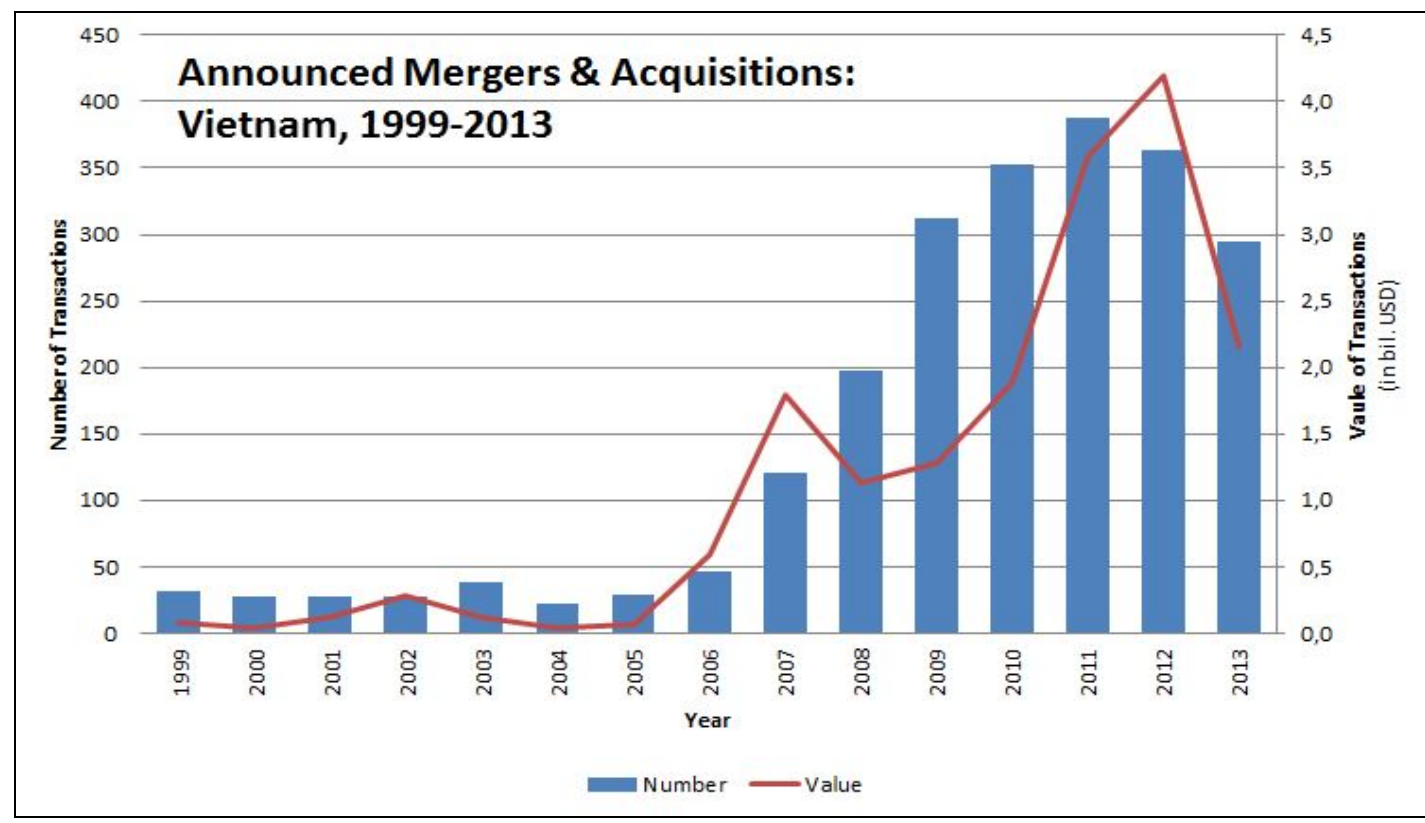

Figure 1. TM\&A activities in Vietnam in 1999-2013

Source: Thomson Financial, Institute of Mergers, Acquisitions and Alliances (IMAA) analysis

In terms of number of business transactions, the business transactions involving domestic enterprises account the majority with $77 \%$. This figure tells us that M\&A activities and transfer occurs vibrantly in Vietnam, although the value of these business transactions are not great. Statistical data shows that business transactions that Vietnamese enterprises have done are often in the scale of 2-5 million US dollars, few of them in the scale of 10-30 million US dollars.

However, a great number of business transactions also demonstrate that the businesses become more active in M\&A activioties and are restructuring their investments, e.g. transfer of projects or companies in which they have engaged in the overheating stage before. In terms of value of business transactions, big business transactions all have foreign factors. Foreign investors accounted for $66 \%$ of value of M\&A transactions. 2011 is the year of big business transaction recorded and it can be concluded about the trend of foreign investors acquiring quality firms of Vietnam.

FMCG is considered as the most attractive with a total transaction value of up to 1 billion US dollars, accounting for $25 \%$ of the total value of M\&A in Vietnam. Outstanding business transactions and acqisition of controlling share proportion show the trend of foreign investors extending value chains and accessing to markets through M\&A.

Business transactions such as Unicharm-Diana, Marico-ICP, Carlsberg-Hue Brewery. In the financial sector have always been constantly interested by foreign investors. The information about Mizuho-Vietcombank, IFC-Vietinbank, PVI-Talant, etc. shows that foreign investors still look forward to strategic investments in large equitized financial institutions. As for real estate sector, the difficulties in 2011 made M\&A activities in this sector take place relatively 
actively. Many transactions involving real estate took place but were not published, mainly domestic partners selling to foreign investors.

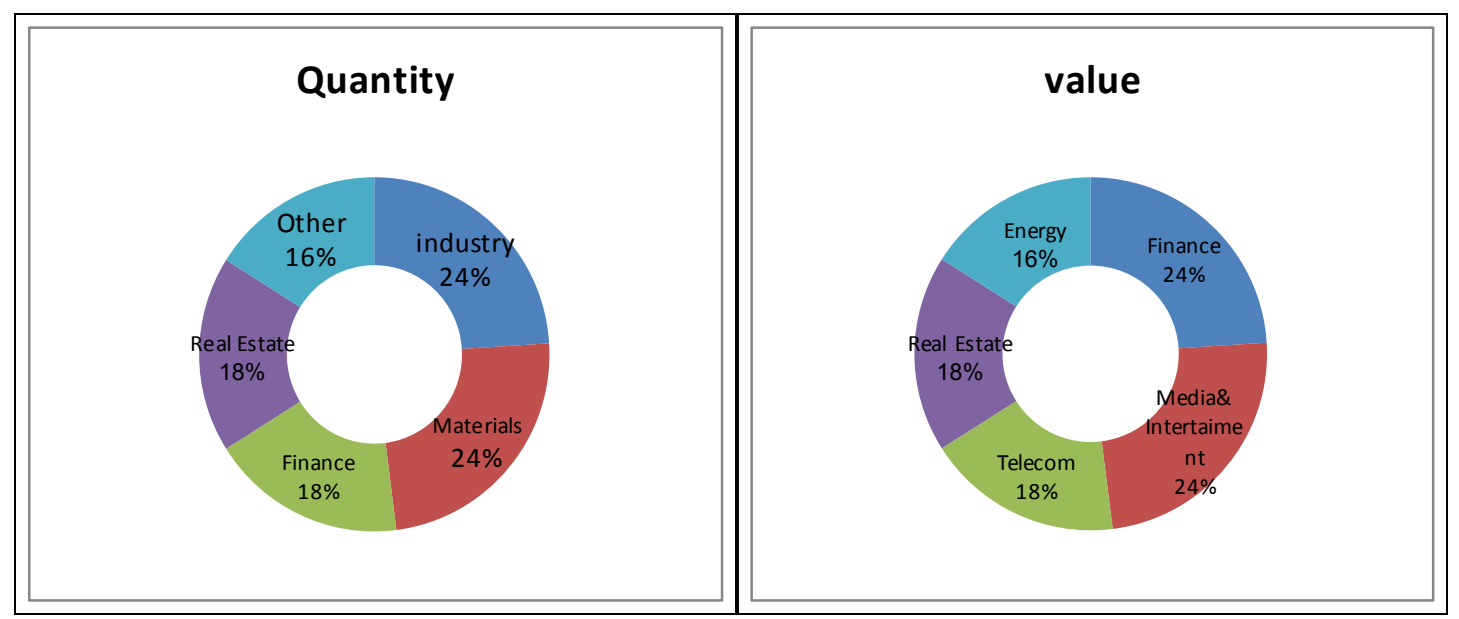

Figure 2. Share of M\&A in Vietnam by industry

Source: Thomson Financial, Institute of Mergers, Acquisitions and Alliances (IMAA) analysis.

\section{Difficulties and Limitations of M\&A Activities in Vietnam}

Legal framework: currently Vietnamese enterprises when implementing M\&A only base on a legal framework for equitization, issuance and listing of securities. The Enterprises Law 2005, the Investment Law 2005, the Competition Law 2004 and the Securities Law 2006 have no specialization. Thus, the definition of M\&A is still very new to Vietnam's market. The entangled point here is that the concepts of mergers and acquisitions have not been standardized and are not regulated uniformly in the relevant laws. Merger under these two laws shall be construed as transfer of all assets, legitimate rights, obligations and interests of the company being merged into the merge receving company (Article 153 of the Enterprises Law 2005).

Information system: The next difficulty of M\&A market in Vietnam at present is the lack of information on target businesses and vague financial information. Due to the fact that the target company always wants to sell at a high price, so it tends to give information beneficial to their business, and really necessary information are not published.

\section{Some Solutions in M\&A Activities in Vietnam}

\subsection{Solution to State Agencies}

4.1.1 Perfection of Legal Framework for Mergers and Acquisitions of Businesses

- To revise the provisions of M\&A to have the uniformity on terminology and content, accelerate the process of drafting legal documents relating to activities of mergers and 
acquisitions of businesses.

- The current regulations have not yet mentioned a merger between a Vietnam's bank and a non-bank credit organiztion, the provisions on Vietnam's banks listed overseas.

- The issues in terms of content of M\&A transactions need to be defined more fully such as business valuation, transfer of assets, financial issues, shares, stocks, employees, taxes, fees, etc.

- To carry out the transaction of mergers and acquisitions in new conditions, the State must build a process to create a mechanism to control and deal with broken issues all the way under market principles, in accordance with international practices, and determine the focal agency, division of tasks, the coordination between departments (Ministry of Planning and Investment, Ministry of Industry and Trade, Ministry of Finance, the State Bank, National Financial Supervisory Commission, Bureau of Competition Management, Securities and Exchange Commission, etc.). The focal agency which receives issues to be handled needs to be given functions and powers necessary and powerful enough to be able to solve the problems, especially in case of system crisis.

\subsubsection{Support Mechanism}

In M\&A activities, information on partners, financial status, legislation, management, market share ... is essential, but the transparency of Vietnam's market is low, which can be detrimental to the buyer or the seller and even to M\&A market in general. The State needs to build a clear information system from the businesses, related parties and managerial agencies. The information is required to be disclosed in an accurate and timely manner to ensure equitable access to information. Clear information also helps enterprises to timely solve problems, to minimize the risk after M\&A, etc.

The State should create conditions for businesses operating in an environment of stability, transparency, equality, always supervise business operations to ensure the stable operation later.

\subsection{Solutions for Businesses}

\subsubsection{Process of Implementing Mergers and Acquisitions of Vietnam's Businesses}

To have an effective transaction of mergers and acquisitions, businesses need a plan and take steps accordingly.

4.2.2 Partner Selection, Determination of Type of Merger and Acquisition Planned to Proceed For target enterprises:

- Determine the goals of the sale of shares (resonant interests, payment methods, right to control ...).

- Define the criteria of the buyer (financial capacity, technological capabilities, management expertise, customers, ranking in the world ...), you can choose more than one bank to have a basis for comparison. Vietnamese businesses before selling their shares to foreign partners 
need to look for businesses with international and global operations, well-known brand and high reputation in financial-banking markets-banking, with experience in the field of international cooperation and ability to support the enterrises for maximum development, not in direct competition with Vietnamese enterprises in various forms.

- Prepare business plans, emphasize its advantages.

- Make sure that the sale of shares must be consistent with the law and with the consent of the parties concerned.

For acquiring enterprises:

- Determine the purpose (expanding market share, increasing capital, diversifying products ...).

- Search suitable candidates according to the criteria set out (scale, customers, personnel, financial capability, competitive position, potential ...), seek information from customers, consulting firms, and other businesses. Acquiring enterprises should have skills in seeing the potential value that others do not see.

- Determine the type of M\&A implemented based on the purposes and laws to determine how to implement.

- Plan a right business strategy.

- Evaluate financial capacity to perform.

- During this period the parties need to reach agreements on security and principle agreements.

\subsubsection{Learning about Status of Finance and Legality}

For target enterprises: Prepare financial statements, records and documents relevant (legal papers, contracts, personnel records ...).

For acquiring enterprises:

- Find out the legal status of property currently owned by the target enterprise, signed contracts, copyright issues, possible rights and obligations, level of compliance of law by the enterprise, whether in litigation or any disputes.

- Financial statements must be audited by reputable companies, analyzing and assessing the business situation (financial indicators, risk reserves, bad debts, receivables and payables, sales revenue, market share ...), the degree of compliance with accounting standards, the situation of asset depreciation, tax obligations, social insurance and allowances for employees.

- Learn about the technology which the target business is using.

- Assess the value of intangible assets such as brand, governance. 


\subsubsection{Identifying Brand}

Corporate brands are intangible assets difficult to value. Both parties need to reassess the properties of both existing brands and brand benefits of the future. The branding must ensure the compliance with customer expectations, the customer trust and the difference with other businesses. There are 4 basic brand strategies depending on the specific characteristics of each business, the level of M\&A of each business transaction:

- Black hole: there will be a brand to be used - usually an acquiring enterprise, and a loss of a brand, as if it disappears into a black hole. This strategy is consistent with the merger of a large enterprise with a reputation and a small business or a business going bankrupt.

- Harvesting: after merging the two brands still exist, but a brand slowly loses over time after gradual transfer of loyalty to the other brand, there will not be a branding effort or marketing of the other brand.

- Marriage: is a combination of two brands of the two businesses, causing concern for customers with both firms, in accordance with the merger of two equal enterprises.

- New beginning: both brands of the two businesses will not bring any major assets; or when there are more than two small businesses merge, this strategy is an effective solution to build brand new properties. To choose which strategy is most appropriate, it is necessary to have a thorough study from customers, business leaders, shareholders and business partners.

\subsubsection{Determining the Value of Business Transactions}

The valuation plays a particularly important role in the success of a business transaction; the price offered must be accepted by both parties. There are many valuation methods, and each method gives a different result; sometimes there is a rather large gap. If the valuation of the financial indicators is relatively easy, the valuation of intangible assets is much more complex.

Intangible assets are brand values, corporate culture, human resources, vision, strategy, market share, management level, geographic location, network of operations, customers, relationships; it is necessary to assess the advantages and risks of these factors after the merger. In some cases, non-financial factors are influencing factors which increase or decrease the value of an M\&A affair, especially in the banking sector. The parties need to hire experts in consulting and valuation in transactions.

For target enterprises: it is necessary to know their own strengths and weaknesses, to know who are the buyers, what they need, what they expect. Normally the purchaser wishes to achieve added value after purchase, which means that after buying the total added value will be higher than the value of each business added together. If the buyer sees the potential, they are willing to pay higher than the market price. The time of sales is also significant.

For acquiring enterprises: it is necessary to carefully learn about the operation of the seller because there may be some information that is not reflected.

The methods which can be used in (tangible) business valuation are cash flow discounting 
method, method of valuation at market price.

(1) Vietnam should improve the market economic institutions to the needs of the M\&A business is increasing. Also, it should create intrinsic needs of the market, the business environment in which to have the high competition among businesses. That was the motivation for enterprises to grow, develop the depth, width, and of course there will be businesses survive, grow, have now bankrupt ... Every major takeovers, environment which will form the demand, sale, merger, joint venture, association between the business to grow more, grow more and better support each other.

(2) Vietnam must build the control channel information, transparency in business activities in general, M\&A activity in particular. Because the M\&A, information on price, brand, market, market share, administration ... are essential for both the buyer and seller. If the information is not controlled, it can transparently causing damage to both buyers, sellers, and impact on other markets such as commodities, securities and banking. Like other markets, the market M\&A activity that line, if an M\&A large place failed or have elements mislead, the consequences for the economy are huge because they can share, left patterns, business, investment ... of that particular business and related businesses were affected.

(3) In addition, Vietnam also needs to complete the legal framework for M\&A. The legal framework will facilitate the transaction is established, the status of the buyer, the seller, the legal consequences after the end of the transaction. Currently, the regulations relating to M\&A to establish the transaction has been formed in the provisions of the Civil Code, the Law on Enterprises, the Law on Investment and the Law on Competition ... However, these regulations just stop at the establishment on a form of M\&A, while the question of the content needs to be defined more fully because the M\&A also has a lot of content related provisions Price enterprises solve financial problems, shares, stock, employees, taxes, fees ... in the course of business and after M\&A.

In addition, the M\&A market is a necessary involvement and consultation of experts have extensive experience in the various fields like law, finance, branding ... so needed programs training to get good experts, brokers, consultants for both the buyer and the seller, who is also providing the best information about the market. There is such a market the new M\&A Vietnam performing well and go into professional.

Indeed, in 2005 investment law has added two new forms of investment are the merger and acquisition of enterprises (companies), buy shares or capital participation in the management of investment activities. DN 2005 Law also provides for the amalgamation, merger companies, transfer of shares DN. In recent years, along with the strong growth of the stock market, the process of equitization of SOEs is happening very aggressive. But a clear legal framework, adequate and transparent basis for the implementation of the transactions mergers and acquisitions business, economic concentration restrictive and unfair competition is still under construction and finishing

M\&A activity is an expression of freedom of business, freedom to dispose of the business owner. In many countries, M\&A activity is recognized by law and regulations fairly complete, 
detailed, especially the water sector M\&A market development such as Europe, America, Japan.

\section{Conclusion}

M\&A activity in the world has existed for a long time but in Vietnam's market M\&A activity is still new. This paper only analyzes the practical situation of M\&A activity currently going on in Vietnam and proposes a number of solutions for appropriate use in Vietnam, such as legal aspects, company brand valuation, M\&A strategy, post M\&A corporate governance, etc.

\section{References}

Anonymous. (n.d.). Retrieved from http://en.wikipedia.org/wiki/Mergers_and_acquisitions Anonymous. (n.d.).
Retrieved from http://www.imaa-institute.org/statistics-mergers-acquisitions.html

Anonymous. (n.d.). Stages of the M\&A Process. The Technology M\&A Guidebook. Retrieved from http://media. wiley.com

Anonymous. (n.d.). The Art of Distressed M\&A: Buying, Selling, and Financing Troubled and Insolvent Companies (Art of M\&A). In H. P. Nesvold, J. Anapolsky \& A. R. Lajoux (Eds.). McGraw-Hill.

Anonymous. (n.d.). The Art of M\&A: A Merger Acquisition Buyout Guide (3rd ed.). Stanley Foster Reed. In A. Lajoux \& H. P. Nesvold (Eds.). McGraw-Hill.

Bui, T. L. (2009). M\&A in the banking sector: Current situation and trends. Journal of Finance Vietnam, 4.

Government. (2012). Scheme of restructuring system of credit institutions for the stage 20; 11-2015, promulgated with Decision 254/QD-TTg of the Prime Minister dated 01 March 2012.

Hogan, W. (2004). Management of Financial Institutions (2nd ed.).

Stephen, A., Ross, R., Westerfield, W., \& Bradford, D. J. (2003). Corporate Finance Fundamentals. McGraw.Hill, Irwin.

Trinh, T. C. (2012). Restructuring banks: Issues raised. Journal of Economy and Forecast, (16).

\section{Copyright Disclaimer}

Copyright for this article is retained by the author(s), with first publication rights granted to the journal. This is an open-access article distributed under the terms and conditions of the Creative Commons Attribution license (http://creativecommons.org/licenses/by/3.0/). 